\title{
PSYCHOLOGICAL WELL-BEING GURU PENDIDIKAN LUAR BIASA DI SLB X BANDUNG BARAT
}

\author{
PSYCHOLOGICAL WELL-BEING OF SPECIAL EDUCATION TEACHERS IN SLB X \\ BANDUNG BARAT
}

\author{
Yusrinda Silvianis Diwanti' ${ }^{1}$, Zainal Abidin ${ }^{2}$ \\ Fakultas Psikologi Universitas Padjadjaran \\ yusrinda11001@mail.unpad.ac.id
}

Received: $18^{\text {th }}$ September 2020; Revised: $21^{\text {st }}$ Januari 2020; Accepted: $2^{\text {nd }}$ February 2021

\begin{abstract}
This study aimed to obtain an overview of psychological well-being from special teacher. There were six dimensions of psychological well-being, namely self-acceptance, positive relations with others, autonomy, environmental mastery, purpose in life, and personal growth. Participants were four special education teachers at SLB X Bandung Barat. Research was conducted using case study method. Retrieval of data used interview techniques. Data were analyzed using thematic data analysis). The results showed that all dimensions of psychological well-being play a role to supporting dan carrying out as special education teachers at SLB X West Bandung. Research can be used as insight to design an intervention that can be used to improve psychological well-being of special education teachers at SLB X West Bandung.
\end{abstract}

Keywords: psychological well-being, special teacher

\begin{abstract}
ABSTRAK
Penelitian ini bertujuan untuk memperoleh gambaran psychological well-being pada guru pendidikan luar biasa. Terdapat enam dimensi psychological well-being, yakni self-acceptance, positive relation with others, autonomy, environmental mastery, purpose in life, dan personal growth. Partisipan adalah empat orang guru SLB X di Kabupaten Bandung Barat. Penelitian dilakukan dengan metode studi kasus. Pengambilan data menggunakan teknik wawancara. Data dianalisis menggunakan analisis data tematik. Hasil menunjukkan bahwa seluruh dimensi psychological well-being berperan untuk mendukung dan menjalani pekerjaan sebagai guru pendidikan luar biasa di SLB X Bandung Barat. Penelitian dapat dimanfaatkan sebagai gambaran untuk merancang intervensi yang dapat digunakan untuk meningkatkan psychological well-being guru pendidikan luar biasa di SLB X Bandung Barat
\end{abstract}

Kata Kunci: psychological well-being, guru pendidikan luar biasa 


\section{PENDAHULUAN}

Menurut pasal 32 ayat 1 dalam Undang-Undang Sistem Pendidikan Nasional No. 20 Tahun 2003, pendidikan khusus merupakan pendidikan peserta didik yang memiliki tingkat kesulitan dalam mengikuti proses pembelajaran karena kelainan fisik, emosional, mental, sosial, dan/atau memiliki potensi kecerdasan dan bakat istimewa. Di Indonesia, sekolah yang menyelenggarakan pendidikan khusus disebut dengan sekolah luar biasa (SLB). Guru yang memiliki kualifikasi untuk menjadi pendidik di sekolah luar biasa adalah guru lulusan dari Pendidikan luar biasa. Pendidikan luar biasa merupakan cabang ilmu pendidikan yang memberikan layanan pendidikan diberikan pada kepada anak-anak berkebutuhan khusus dan penyandang cacat (Suherman, 2012). Ketika melaksanakan fungsinya, guru pendidikan luar biasa melaksanakan tiga jenis layanan, yaitu layanan prevensi, layanan intervensi, dan layanan kompensasi (Suherman, 2012).

Kesehatan mental pada guru luar biasa menjadi satu topik yang sering kali disorot. Menurut Kim dan Lim (2016) kesehatan mental adalah hal penting bagi guru pendidikan luar biasa. Pertama, guru pendidikan luar biasa harus menghadapi sulitnya mengajar anak dengan kebutuhan khusus. Kedua, guru pendidikan luar biasa harus menghabiskan waktu untuk memberikan instruksi yang lebih jelas dan mudah bagi anak dengan kebutuhan khusus. Dua alasan tersebut dapat menyebabkan stres dan meningkatkan job burnout bagi guru pendidikan luar biasa (Kim \& Lim, 2016). Pada penelitian yang dilakukan oleh Platsidou (2010) guru pendidikan luar biasa juga lebih rentan untuk mengembangkan stres dibandingkan dengan guru pendidikan umum karena pekerjaan guru pendidikan luar biasa yang lebih menyebabkan kelelahan. Hal ini didukung oleh penelitian yang dilakukan oleh Rothmann (2014) bahwa guru pendidikan luar biasa yang kurang memiliki psychological well-being cenderung menangani tuntutan pekerjaan sama buruknya dengan individu yang mengalami stres atau job burnout. 
Mengetahui tingkat psychological well-being guru merupakan hal penting untuk perlindungan kesehatan mental serta pengembangan profesional dan pribadi guru. Penelitian yang berkaitan dengan penentuan tingkat kesejahteraan guru dan faktor yang mempengaruhi kesejahteraan guru dianggap penting bagi lingkungan sekolah. Hal ini dikarenakan pengembangan program intervensi untuk menungkatkan kualitas pendidikan memerlukan penelitian yang menggambarkan psychological wellbeing guru (Özü et al., 2017). Penelitian menunjukkan psychological well-being memengaruhi proses berpikir adaptif dan kreatif, perilaku prososial, dan kesehatan fisik yang baik (Ilgan, Özü-cengiz, Ata, \& Akram, 2015).

Ryff (2013) mendefinisikan psychological well-being sebagai tingkat individu merasa hidupnya memiliki arti, tujuan dan arah; memandang hidupnya sendiri sesuai dengan keyakinan pribadi; tingkat memanfaatkan bakat dan potensi pribadi dalam pertumbuhan pribadi; seberapa baik mengelola situasi kehidupan; kedalaman hubungan dengan orang lain; serta pengetahuan dan penerimaan yang dimiliki tentang diri sendiri, termasuk kesadaran akan keterbatasan diri. Psychological well-being terdiri dari enam dimensi, yaitu self-acceptance, positive relation with others, autonomy, environmental mastery, purpose in life, dan personal growth.

Secara teoretis, Ryff (2013) mendefinisikan enam dimensi sebagai berikut (1) self-acceptance merupakan rasa penerimaan diri individu, yang dinilai sebagai ciri utama kesehatan mental individu serta karakteristik dari kematangan, fungsi optimal dan aktualisasi diri, termasuk penerimaan terhadap kehidupan masa lalu. (2) Positive relation with others merupakan penekanan mengenai pentingnya hubungan interpersonal yang hangat dan saling percaya dengan individu lain, termasuk pengaktualisasian diri dan kehangatan. (3) Autonomy terdiri dari pengarahan diri, kemandirian, dan regulasi perilaku diri. (4) Environmental mastery merupakan kemampuan individu untuk memilih atau menciptakan lingkungan sesuai dengan kondisi psikisnya yang membuat individu berkembang dan mengubah 
lingkungan secara kreatif melalui aktivitas fisik atau mental. (5) Purpose in life merupakan adanya tujuan dan makna hidup dalam kehidupan individu. Hal ini menekankan pemahaman yang jelas tentang tujuan hidup, rasa keterarahan, dan perilaku yang bertujuan yang berkontribusi pada perasaan bahwa hidupnya bermakna. (6) Personal growth merupakan fungsi psikologis yang optimal juga mengembangkan potensi individu.

SLB X adalah sebuah sekolah luar biasa (SLB) swasta di daerah Bandung Barat yang menyediakan tiga fungsi pendidikan luar biasa yaitu prevensi, intervensi, dan kompensasi. SLB X memiliki 16 siswa dengan klasifikasi berkebutuhan yang berbeda-beda, yaitu tuna grahita (intellectual disability), autism spectrum disorder, dan cerebral palsy dalam jenjang taman kanak-kanak, sekolah dasar, dan sekolah menengah pertama. Tenaga pendidik di SLB X terdiri dari seorang kepala sekolah, seorang wakil kepala sekolah bidang kurikulum, seorang wakil kepala sekolah bidang kesiswaan, dan lima guru kelas. Seluruh guru merupakan lulusan dari jurusan pendidikan luar biasa.

Di Indonesia, khususnya Kabupaten Bandung Barat, belum ada penelitian mengenai psychological well-being pada SLB X di Kabupaten Bandung Barat. Mengetahui keadaan psychological well-being dari guru pendidikan luar biasa di SLB X Bandung Barat merupakan hal yang penting. Hal ini dikarenakan guru yang memiliki psychological well-being yang optimal dapat menjadi guru yang dapat berpikir adaptif dan kreatif, mampu menunjukkan perilaku prososial, serta memiliki kesehatan fisik optimal yang dapat mendukung profesinya sebagai guru bagi anak berkebutuhan khusus. Selain itu, meningkatkan psychological well-being pada guru berhubungan dengan meningkatkan academic achievement dan mengurangi risiko serta masalah perilaku pada anak yang dididik (Sisask et al., 2014). Sehingga tujuan dari penelitian ini adalah untuk menggambarkan psychological well-being dari guru pendidikan luar biasa yang bekerja di SLB X Bandung Barat. Penelitian ini dapat memberikan gambaran 
bagi yayasan yang mengelola SLB dalam meningkatkan psychological well-being guru pendidikan luar biasa di SLB X Bandung Barat.

\section{METODE PENELITIAN}

Penelitian ini menggunakan metode kualitatif, yaitu studi kasus. Teknik sampling yang digunakan dalam penelitian ini adalah purposive sampling. Partisipan penelitian dalam penelitian ini adalah empat guru pendidikan luar biasa yang bekerja di SLB X Bandung Barat. Profil partisipan dapat dilihat pada tabel 2 .

Teknik pengambilan data yang digunakan adalah teknik wawancara. Proses pengambilan data dilakukan pada tanggal 18 Mei 2018 dalam durasi waktu 45-60 menit. Jenis wawancara yang digunakan adalah one on one interview, yaitu proses pengambilan data di mana peneliti memberikan pertanyaan dan mencatat jawaban dari seorang partisipan pada satu waktu (Creswell, 2012). Panduan wawancara disusun berdasarkan dimensi psychological well-being (Ryff, 2013). Kisi-kisi wawancara psychological wellbeing dapat dilihat pada tabel 1.

Tabel 1. Kisi-Kisi Pertanyaan Psychological Well-being

\begin{tabular}{|c|c|c|}
\hline Konstruk & Dimensi & Item Pertanyaan \\
\hline \multirow[t]{3}{*}{$\begin{array}{l}\text { Pyschological } \\
\text { Well-being }\end{array}$} & Self-acceptance & $\begin{array}{l}\text { - Apa makna hidup anda sebagai guru pendidikan luar biasa? } \\
\text { - Menurut anda, apa kekuatan dan kelemahan diri? } \\
\text { - Bagaimana anda menerima kekuatan dan kelemahan tersebut? } \\
\text { - Ceritakan kegagalan yang dirasakan di masa lalu. } \\
\text { - Bagaimana cara anda mengatasi kegagalan tersebut? }\end{array}$ \\
\hline & $\begin{array}{l}\text { Positive } \\
\text { Relation } \\
\text { Others }\end{array}$ & $\begin{array}{l}\text { - Apakah anda memiliki hubungan dekat dengan orang lain? bisa } \\
\text { diceritakan? } \\
\text { - Bagaimana hubungan anda dengan orang-orang tersebut? } \\
\text { - Bagaimana anda menjalin hubungan dekat dengan orang lain? }\end{array}$ \\
\hline & Autonomy & $\begin{array}{l}\text { - Apa yang membuat anda menjadi guru pendidikan luar biasa? } \\
\text { - Apa yang membuat anda tetap bertahan menjadi guru pendidikan luar } \\
\text { biasa? } \\
\text { - Apa yang menghambat pekerjaan anda? } \\
\text { - Bagaimana anda mengatasinya? }\end{array}$ \\
\hline
\end{tabular}




\begin{tabular}{ll} 
Environmental & - Adakah tuntutan atau ekspektasi yang diberikan dari lingkungan pada \\
Mastery & anda? \\
& - Bagaimana perasaan anda dengan tuntutan lingkungan? \\
& - Bagaimana anda mengatasi tuntutan lingkungan yang tinggi pada diri \\
& anda? \\
\hline Purpose in Life & - Adakah tujuan yang ingin anda capai? Ceritakan. \\
& - Bisakan tujuan tersebut dibagi menjadi tujuan jangka pendek dan \\
& jangka panjang? Bisa diceritakan. \\
\hline Personal & - Apakah selama ini anda merasa ada perkembangan signifikan sebagai \\
Growth & individu? \\
& - Bagaimana anda tetap berkembang sebagai individu dengan kesibukan \\
& dan tuntutan lingkungan?
\end{tabular}

Analisis data pada penelitian kualitatif ini menggunakan metode thematic analysis, yaitu metode untuk mengidentifikasi, menganalisis, dan melaporkan pola (tema) dalam data (Braun \& Clarke, 2006; Clarke \& Braun, 2017). Penelitian ini menggunakan theoretical thematic analysis yang didorong oleh minat teoretis pada bidang psychological well-being. Proses dimulai dengan membuat transkrip verbatim dari hasil wawancara. Selanjutnya data diorganisasikan dengan mencocokkan data dengan kisi-kisi wawancara yang telah disusun, dan membuat kode hasil wawancara. Kemudian peneliti menentukan tema pada dimensi tertentu, misalnya dimensi self-acceptance. Hasil dianalisis untuk mendapatkan kesimpulan dari dimensi yang dibahas dan mengintegrasikan tiap kesimpulan di antara partisipan. Hasil analisis data wawancara berdasarkan dimensi psychological well-being dapat dilihat pada tabel 3.

\section{HASIL PENELITIAN}

\section{Profil Partisipan}

Terdapat empat orang guru perempuan yang menjadi partisipan dalam penelitian ini. Keempat partisipan merupakan guru di SLB X Bandung Barat. Keempat guru juga merupakan wali kelas yang bertanggung jawab untuk melaksanakan kegiatan belajar mengajar pada pukul 07.30 hingga 11.30 WIB. Sebagai pegawai yayasan, keempat guru diharuskan untuk bekerja di sekolah pukul 07.00 hingga 16.00 
WIB. Selain itu, keempat partisipan juga memiliki tanggung jawab lain, yaitu melengkapi administrasi dan menyesuaikan kegiatan belajar mengajar dengan visi misi yayasan yang berbasiskan agama Islam. Selain melaksanakan kegiatan belajar mengajar, keempat guru juga memberikan pendampingan terkait dengan kemampuan bantu diri siswa berkebutuhan khusus termasuk menyuapi saat makan dan membersihkan ketika siswa buang air kecil atau buang air besar. Profil partisipan penelitian dapat dilihat pada tabel 2 .

Tabel 2. Profil Partisipan Penelitian

\begin{tabular}{|c|c|c|c|c|}
\hline \multirow{2}{*}{ Keterangan } & \multicolumn{4}{|c|}{ Partisipan Penelitian } \\
\hline & Subjek 1 & Subjek 2 & Subjek 3 & Subjek 4 \\
\hline Jenis Kelamin & Perempuan & Perempuan & Perempuan & Perempuan \\
\hline $\begin{array}{c}\text { Usia saat } \\
\text { wawancara } \\
\text { dilakukan } \\
\end{array}$ & 30 tahun & 53 tahun & 30 tahun & 29 tahun \\
\hline Suku Bangsa & Jawa & Sunda & Sunda & Sunda \\
\hline Agama & Islam & Islam & Islam & Islam \\
\hline Pendidikan & $\begin{array}{c}\text { S1-Pendidikan Luar } \\
\text { Biasa }\end{array}$ & $\begin{array}{l}\text { S1-Pendidikan } \\
\text { Luar Biasa }\end{array}$ & $\begin{array}{c}\text { S1-Pendidikan } \\
\text { Luar Biasa }\end{array}$ & $\begin{array}{c}\text { S1-Pendidikan Luar } \\
\text { Biasa }\end{array}$ \\
\hline Pekerjaan & Guru Tetap Yayasan & PNS - Guru & $\begin{array}{l}\text { Guru Tetap } \\
\text { Yayasan }\end{array}$ & Guru Tetap Yayasan \\
\hline $\begin{array}{c}\text { Status } \\
\text { Pernikahan }\end{array}$ & Belum Menikah & Menikah & Menikah & Menikah \\
\hline Jumlah Anak & - & $\begin{array}{l}\text { 2 anak: } \\
\text { 1. Usia } 23 \text { tahun } \\
\text { 2. Usia } 18 \text { tahun }\end{array}$ & $\begin{array}{l}\text { 2 anak: } \\
\text { 1. Usia } 6 \text { tahun } \\
\text { 2. Usia } 1 \text { tahun }\end{array}$ & $\begin{array}{c}1 \text { anak: } \\
\text { 1. Usia } 4 \text { tahun }\end{array}$ \\
\hline $\begin{array}{c}\text { Lama berprofesi } \\
\text { sebagai guru }\end{array}$ & 5 tahun & 30 tahun & 6 tahun & 6 tahun \\
\hline $\begin{array}{c}\text { Lama mengajar } \\
\text { di sekolah saat } \\
\text { dilakukan } \\
\text { wawancara }\end{array}$ & 2 tahun & 4 tahun & 6 tahun & 6 tahun \\
\hline $\begin{array}{c}\text { Jenis anak } \\
\text { berkebutuhan } \\
\text { khusus yang } \\
\text { pernah } \\
\text { ditangani }\end{array}$ & $\begin{array}{c}\text { Tuna grahita } \\
\text { (intelelectual } \\
\text { disability, down } \\
\text { syndrome), autism } \\
\text { spectrum disorder } \\
\text { tingkat taman kanak- } \\
\text { kanak }\end{array}$ & $\begin{array}{l}\text { Tuna grahita } \\
\text { (intellectual } \\
\text { disability), } \\
\text { cerebral palsy } \\
\text { tingkat sekolah } \\
\text { menengah } \\
\text { pertama }\end{array}$ & $\begin{array}{l}\text { Tuna grahita } \\
\text { (intellectual } \\
\text { disability), } \\
\text { cerebral palsy, } \\
\text { tingkat sekolah } \\
\text { dasar }\end{array}$ & $\begin{array}{c}\text { Tuna grahita } \\
\text { (intellectual disability, } \\
\text { down syndrome), } \\
\text { autism spectrum } \\
\text { disorder tingkat } \\
\text { sekolah dasar }\end{array}$ \\
\hline $\begin{array}{l}\text { Sistem belajar } \\
\text { di kelas }\end{array}$ & atu & nangani 3 ora & swa dengan keb & an khusus \\
\hline
\end{tabular}


Keempat partisipan memberikan pemaknaan berbeda yang dirasakan oleh setiap individu sebagai guru pendidikan luar biasa. Hasil mengenai keadaan psychological well-being pada partisipan penelitian akan dibahas pada setiap partisipan melalui masing-masing dimensi pembentuk psychological wellbeing. Tema hasil wawancara kepada empat partisipan berdasarkan dimensi psychological well-being dapat dilihat pada tabel 3 .

\section{Tabel 3. Tema Jawaban Partisipan}

\begin{tabular}{|c|c|c|c|c|}
\hline Tema & Subjek 1 & Subjek 2 & Subjek 3 & Subjek 4 \\
\hline \multicolumn{5}{|c|}{ Dimensi Self-acceptance } \\
\hline Makna hidup & $\begin{array}{l}\text { Belajar bersyukur } \\
\text { dan tetap berusaha } \\
\text { mengembangkan diri }\end{array}$ & $\begin{array}{l}\text { Amanah dan tetap } \\
\text { belajar }\end{array}$ & $\begin{array}{l}\text { Bersyukur dan positif } \\
\text { dalam menjalani } \\
\text { kehidupan }\end{array}$ & $\begin{array}{l}\text { Bersyukur dan } \\
\text { berusaha menjadi } \\
\text { manusia } \\
\text { bermanfaat }\end{array}$ \\
\hline $\begin{array}{c}\text { Makna } \\
\text { kekuatan diri }\end{array}$ & $\begin{array}{l}\text { Menjadi hal yang } \\
\text { mendukung performa } \\
\text { kerja }\end{array}$ & $\begin{array}{l}\text { Menjadi hal yang } \\
\text { mendukung } \\
\text { performa kerja }\end{array}$ & $\begin{array}{l}\text { Menjadi hal yang } \\
\text { mendukung performa } \\
\text { kerja }\end{array}$ & $\begin{array}{l}\text { Menjadi hal yang } \\
\text { mendukung } \\
\text { performa kerja }\end{array}$ \\
\hline $\begin{array}{c}\text { Makna } \\
\text { kelemahan diri }\end{array}$ & $\begin{array}{lr}\text { Hal yang harus } \\
\text { diperbaiki } \\
\text { ditingkatkan }\end{array}$ & $\begin{array}{lr}\text { Hal yang } & \text { harus } \\
\text { diperbaiki } & \text { atau } \\
\text { ditingkatkan } & \\
\end{array}$ & $\begin{array}{lr}\text { Hal yang harus } \\
\text { diperbaiki } \\
\text { ditingkatkan }\end{array}$ & $\begin{array}{lr}\text { Hal yang } & \text { harus } \\
\text { diperbaiki } & \text { atau } \\
\text { ditingkatkan } & \\
\end{array}$ \\
\hline $\begin{array}{l}\text { Mengatasi } \\
\text { kegagalan }\end{array}$ & $\begin{array}{l}\text { Belajar menerima } \\
\text { dan bangkit }\end{array}$ & $\begin{array}{lr}\text { Berusaha } & \text { untuk } \\
\text { belajar } & \text { dari } \\
\text { kegagalan } & \\
\end{array}$ & $\begin{array}{l}\text { Berusaha untuk } \\
\text { melupakan kegagalan }\end{array}$ & $\begin{array}{l}\text { Belajar } \\
\text { kegagalan }\end{array}$ \\
\hline \multicolumn{5}{|c|}{ Dimensi Positive Relation with Others } \\
\hline $\begin{array}{l}\text { Mampu } \\
\text { membangun } \\
\text { hubungan } \\
\text { hangat dengan }\end{array}$ & $\begin{array}{l}\text { - Rekan guru satu unit } \\
\text { sekolah } \\
\text { - Orang tua siswa }\end{array}$ & $\begin{array}{l}\text { - Rekan guru satu } \\
\text { unit sekolah } \\
\text { - Rekan guru unit } \\
\text { lain } \\
\text { - Orang tua siswa } \\
\end{array}$ & $\begin{array}{l}\text { Rekan guru satu unit } \\
\text { sekolah }\end{array}$ & $\begin{array}{l}\text { Rekan guru satu } \\
\text { unit sekolah }\end{array}$ \\
\hline $\begin{array}{l}\text { Strategi untuk } \\
\text { membangun } \\
\text { hubungan } \\
\text { hangat }\end{array}$ & $\begin{array}{l}\text { - Kedekatan } \\
\text { emosional } \\
\text { - Empati }\end{array}$ & $\begin{array}{ll}\text { - } & \text { Kedekatan } \\
& \text { emosional } \\
\text { - } & \text { Komunikasi } \\
\text { - } & \text { Diskusi } \\
\text { - Kerja sama } \\
\end{array}$ & $\begin{array}{l}\text { - Ramah } \\
\text { - Bersikap baik }\end{array}$ & $\begin{array}{l}\text { - Diskusi } \\
\text { - Berbagi } \\
\text { - Melakukan } \\
\text { kegiatan } \\
\text { bersama } \\
\end{array}$ \\
\hline \multicolumn{5}{|c|}{ Dimensi Autonomy } \\
\hline $\begin{array}{l}\text { Alasan } \\
\text { menjadi guru } \\
\text { PLB }\end{array}$ & $\begin{array}{l}\text { Pengalaman } \\
\text { berempati pada } \\
\text { teman yang } \\
\text { berkebutuhan khusus }\end{array}$ & $\begin{array}{l}\text { Melihat keunikan } \\
\text { pada anak } \\
\text { berkebutuhan } \\
\text { khusus }\end{array}$ & $\begin{array}{l}\text { Ingin } \\
\text { mengembangkan } \\
\text { kemampuan anak } \\
\text { berkebutuhan khusus }\end{array}$ & $\begin{array}{l}\text { Melihat } \\
\text { keistimewaan } \\
\text { pada anak } \\
\text { berkebutuhan } \\
\text { khusus }\end{array}$ \\
\hline $\begin{array}{l}\text { Hambatan } \\
\text { sebagai guru } \\
\text { PLB }\end{array}$ & $\begin{array}{l}\text { Media belajar kurang } \\
\text { tersedia }\end{array}$ & $\begin{array}{l}\text { Komunikasi } \\
\text { dengan orang tua } \\
\text { siswa }\end{array}$ & $\begin{array}{l}\text { Manajemen waktu } \\
\text { antara pekerjaan dan } \\
\text { keluarga }\end{array}$ & $\begin{array}{l}\text { Perbedaan } \\
\text { program }\end{array}$ \\
\hline
\end{tabular}




\begin{tabular}{|c|c|c|c|c|}
\hline Tema & Subjek 1 & Subjek 2 & Subjek 3 & Subjek 4 \\
\hline & & & & $\begin{array}{ll}\text { sekolah } & \text { dan } \\
\text { rumah siswa } & \end{array}$ \\
\hline $\begin{array}{l}\text { Alasan tetap } \\
\text { menjadi guru } \\
\text { pendidikan } \\
\text { luar biasa }\end{array}$ & $\begin{array}{l}\text { Sesuai dengan cita- } \\
\text { cita }\end{array}$ & $\begin{array}{l}\text { Bentuk beribadah } \\
\text { dan penghasilan }\end{array}$ & $\begin{array}{l}\text { Kasih sayang pada } \\
\text { siswa } \\
\text { penghasilan }\end{array}$ & $\begin{array}{l}\text { Kasih sayang pada } \\
\text { siswa dan } \\
\text { penghasilan }\end{array}$ \\
\hline \multicolumn{5}{|c|}{ Dimensi Purpose In Life } \\
\hline Tujuan hidup & $\begin{array}{l}\text { Meningkatkan } \\
\text { kompetensi diri dan } \\
\text { membantu anak } \\
\text { berkebutuhan khusus } \\
\text { lain }\end{array}$ & $\begin{array}{l}\text { Meningkatkan } \\
\text { kemampuan siswa }\end{array}$ & Keluarga & Keluarga \\
\hline \multicolumn{5}{|c|}{ Dimensi Personal Growth } \\
\hline $\begin{array}{l}\text { Perkembangan } \\
\text { sebagai } \\
\text { individu }\end{array}$ & $\begin{array}{lr}\text { Memperbaiki } \\
\text { kelemahan } \\
\text { menambah diri, } \\
\begin{array}{l}\text { pengetahuan } \\
\text { relevan yang } \\
\text { pekerjaan }\end{array} \\
\end{array}$ & $\begin{array}{l}\text { Menambah } \\
\text { keterampilan yang } \\
\text { relevan dengan } \\
\text { pekerjaan }\end{array}$ & $\begin{array}{l}\text { Berusaha mengikuti } \\
\text { perkembangan zaman }\end{array}$ & $\begin{array}{l}\text { Tidak merasa ada } \\
\text { perkembangan }\end{array}$ \\
\hline \multicolumn{5}{|c|}{ Dimensi Environmental Mastery } \\
\hline $\begin{array}{l}\text { Cara } \\
\text { mengatasi } \\
\text { tuntutan } \\
\text { lingkungan }\end{array}$ & $\begin{array}{l}\text { Mengembangkan } \\
\text { pengetahuannya } \\
\text { dengan membaca } \\
\text { artikel dan berita } \\
\text { terbaru mengenai } \\
\text { anak berkebutuhan } \\
\text { khusus dan terapi } \\
\text { melalui internet }\end{array}$ & $\begin{array}{lr}\text { Sering } & \text { berdiskusi } \\
\text { dengan rekan, } \\
\text { staff yayasan, dan } \\
\text { orang tua siswa }\end{array}$ & $\begin{array}{lr}\text { Berusaha } & \text { untuk } \\
\text { menyelesaikan } & \text { tugas } \\
\text { dengan } & \text { cepat, } \\
\text { sehingga } & \text { seluruh } \\
\text { tugas } & \text { dapat } \\
\text { diselesaikan } & \end{array}$ & $\begin{array}{l}\text { Sering berdiskusi } \\
\text { dengan rekan dan } \\
\text { membaca } \\
\text { referensi untuk } \\
\text { menyesuaikan diri } \\
\text { dengan tuntutan } \\
\text { lingkungan }\end{array}$ \\
\hline
\end{tabular}

\section{Gambaran Psychological Well-being Subjek 1}

Berdasarkan wawancara yang dilakukan kepada Subjek 1 (30 tahun), Subjek 1 menjadi guru pendidikan luar biasa karena ia memiliki teman yang berkebutuhan khusus ketika masih belajar di sekolah dasar. Hal tersebut terlihat melalui pernyataan Subjek 1 sebagai berikut "saya lihat teman yang ngga punya teman dan sering diganggu oleh teman sekelas yang lain. Makanya saya mau jadi guru PLB.” Dimensi autonomy menjadi aspek yang mengarahkan Subjek 1 mengambil jurusan pendidikan luar biasa di universitas pendidikan negeri di Bandung agar dapat membantu anak-anak berkebutuhan khusus. Tujuan tersebut juga membuatnya dapat mengatasi hambatan yang muncul dan mencari cara lain 
agar hambatan tersebut tidak mengganggu performa kerjanya. Hal tersebut membantunya untuk mengembangkan dirinya dalam dimensi personal growth berdasarkan pernyataan Subjek 1 berikut “capek sih jadi guru PLB tapi motivasi itu yang buat saya terus berusaha menjadi guru yang baik.”

Selama perkembangan hidupnya hingga sekarang, Subjek 1 menerima karakteristik dirinya dengan mengetahui kekuatan dan kelemahan dirinya dalam dimensi self-acceptance. Hal tersebut yang membuatnya dapat memaknai kehidupan yang ia jalani sekarang. Selain itu, self-acceptance Subjek 1 lakukan dengan menerima kegagalan di masa lalu. Hal tersebut diperoleh melalui pernyataan Subjek 1 berikut, "saya malu dan sedih saat tidak lulus ujian nasional saat SMA, tapi akhirnya saya sadar kalau saya harus bangkit lagi. Akhirnya saya coba untuk ujian paket A dan ikut tes universitas negeri." Subjek 1 menilai kegagalannya sebagai pengalaman hidup berharga dan lebih bersyukur dengan kehidupan.

Jika ditinjau dari dimensi positive relation with others, Subjek 1 memiliki hubungan dekat dengan rekan-rekan guru dan juga orang tua siswa yang dibangun dengan sikap ramah dan kedekatan emosional. Hal tersebut diperoleh melalui pernyataan Subjek 1 berikut, "saya mah ngajak ngobrol saja rekan guru sama orang tua siswa. Kalau mau curhat juga boleh, kan siapa sih ya yang ngga punya masalah, semua orang pasti punya masalah. Jadi belajar empati juga." Subjek 1, rekan guru serta orang tua siswa juga sering berkomunikasi mengenai perkembangan siswa di kelas.

Dalam dimensi environmental mastery, Subjek 1 berusaha untuk tetap tenang menjalani tuntutan pekerjaan, berusaha agar masalah pribadi tidak memengaruhi performa kerjanya dan tetap meningkatkan pengetahuannya tentang anak berkebutuhan khusus dan terapi. Hal tersebut diperoleh melalui pernyataan Subjek 1 berikut, “suka pusing sih sama kerjaan, tapi ya tetap harus tenang. Dijalani saja. Kalau lagi ada masalah ya pokoknya usahakan untuk tidak mengganggu pas ngajar siswa."

Cara tersebut sejalan dengan tujuan yang ia miliki dalam dimensi purpose in life, yaitu memiliki lembaga pendidikan bagi anak berkebutuhan khusus dan mengambil jenjang pendidikan master 
mengenai terapi pada anak berkebutuhan khusus. Hal tersebut diperoleh melalui pernyataan Subjek 1 berikut "kedepannya saya ingin punya sekolah sendiri, tapi tetap harus belajar dulu. Kalau bisa saya mau ambil program magister sih dalam waktu dekat."

\section{Gambaran Psychological Well-being Subjek 2}

Subjek 2 (53 tahun) menjadi guru pendidikan luar biasa dikarenakan menemukan keunikan pada anak berkebutuhan khusus dan keluarga. Hal tersebut diperoleh melalui pernyataan Subjek 2 berikut, “kalau kita mau usaha untuk lebih dekat dengan anak berkebutuhan khusus pasti kita bisa lihat kalau mereka anak yang baik dan unik, ngga sama satu sama lain. Mereka juga punya latar belakang keluarga yang beda-beda yang akhirnya membuat kita juga punya cara beda-beda buat menghadapi mereka."

Jika ditinjau dari dimensi autonomy, menjadi guru pendidikan luar biasa juga ia anggap sebagai bentuk beribadah, selain untuk mendapatkan penghasilan. Sebagai guru pendidikan luar biasa, Subjek 2 menyadari adanya kekurangan dalam dirinya yang membuat tidak dapat maksimal untuk bekerja sebagai guru. Dalam dimensi self-acceptance, Subjek 2 berusaha untuk tidak fokus pada kekurangan diri, namun berusaha maksimal dalam pelajaran lain. Hal tersebut diperoleh melalui pernyataan Subjek 2 berikut, "saya sebenarnya sedih ngga bisa ikut ngajarin renang. Jadi anak kelas saya harus diajarkan oleh guru kelas lain. Tapi ini membuat saya berusaha untuk maksimal di mata pelajaran lain”

Dalam dimensi personal growth, keinginan untuk berusaha memberikan yang terbaik mendorong Subjek 2 untuk mengatasi hambatan yang muncul dalam pekerjaan dan tidak mudah menyerah dengan situasi serta keadaan yang memberikan tekanan. Pada dimensi positive relation with others, Subjek 2 memiliki hubungan hangat dengan rekan-rekan guru dan orang tua siswa dengan cara memberikan kasih sayang seperti pada keluarga sendiri. Hal tersebut diperoleh melalui pernyataan Subjek 2 berikut "kalau ke guru-guru di sini kan kebanyakan usianya lebih muda ya, seumuran sama anak saya. Jadi saya kayak 
ke anak sendiri saja, sering ngobrol, makan bareng, dan saling bantu. Sama orang tua siswa juga sama, jadi akrab karena sering ngobrol tentang perkembangan anaknya"

Jika ditinjau dari dimensi purpose in life, ia berharap dapat mengembangkan potensi siswa menjadi optimal dan bermanfaat bagi orang lain. Hal tersebut diperoleh melalui pernyataan Subjek 2 berikut, "saya juga sudah tua, anak sudah pada dewasa. Sudah ngga ada yang mau dikejar lagi, jadi saya hanya ingin siswa-siswa saya bisa optimal potensinya dan saya bisa bermanfaat buat orang lain"

Subjek 2 merasa bahwa hidupnya patut disyukuri. Jika ditinjau dari dimensi environmental mastery Subjek 2 menyadari bahwa dirinya harus tetap berkembang dengan belajar untuk mengikuti tuntutan lingkungan. Salah satunya adalah belajar teknologi karena ia merasa tertinggal dalam hal teknologi dibandingkan guru-guru lainnya.

\section{Gambaran Psychological Well-being Subjek 3}

Pada dimensi autonomy, Subjek 3 (30 tahun) menjadi guru pendidikan luar biasa dikarenakan memiliki tujuan untuk dapat mengembangkan kemampuan yang dimiliki oleh anak berkebutuhan khusus dengan keterbatasan. Selain itu juga sebagai bentuk beribadah dan bersyukur kepada Tuhan. Hal ini yang mendorongnya tetap bertahan menjadi guru pendidikan luar biasa. Pada dimensi positive relation with others, Subjek 3 juga memiliki hubungan cukup dekat dengan rekan-rekan guru satu unit dengan cara membangun hubungan baik dan ramah pada rekan guru. Ia tidak merasa dekat dengan rekan guru unit lain, staf yayasan, dan orang tua siswa dikarenakan kelemahan dirinya. Hal tersebut diperoleh melalui pernyataan Subjek 3 berikut, "saya kan orangnya cenderung pendiem dan ngga gampang deket sama orang lain. Jadi dekatnya sama guru-guru di unit ini saja."

Pada dimensi self-acceptance, Subjek 3 mengenali kekuatan dan kelemahan dirinya yang dapat memengaruhi performa kerjanya. Ia berusaha untuk mengatasi kelemahannya dengan menonjolkan 
kekuatan dirinya. Hal tersebut diperoleh melalui pernyataan Subjek 3 berikut, "kekuatan saya sebagai guru adalah peduli dan juga tegas kepada siswa. Jadi biasanya saya yang menjadi kesiswaan untuk mengingatkan siswa kalau berperilaku yang kurang sesuai." Subjek 3 juga berusaha untuk tidak mengingat kegagalan masa lalu dan tetap berkembang sebagai individu.

Jika ditinjau dari dimensi personal growth, Subjek 3 berusaha untuk tetap memotivasi diri untuk dapat mengikuti perkembangan dan tuntutan zaman yang berbeda-beda dengan membuka diri untuk belajar. Pada dimensi environmental mastery, Subjek 3 merasa kesulitan dalam hal manajemen waktu. Ia berusaha mengatasinya dengan mengerjakan seluruh tugas dengan cepat dibandingkan guru-guru lainnya. Hal ini diperoleh melalui pernyataan Subjek 3 berikut, "kesulitan saya sehari-hari karena harus bisa mengatur waktu untuk keluarga dan pekerjaan. Mau ngga mau harus bisa cepat mengerjakan pekerjaan rumah dan sekolah."

Pada dimensi purpose in life, Subjek 3 juga fokus pada tujuan jangka panjangnya yang berkaitan dengan keluarga, sehingga ia menjadikan pekerjaan sebagai guru pendidikan luar biasa ini sebagai media untuk dapat berinvestasi bagi anak-anaknya kelak.

\section{Gambaran Psychological Well-being Subjek 4}

Pada dimensi autonomy, Subjek 4 (29 tahun) menjadi guru pendidikan luar biasa dikarenakan ia melihat adanya keistimewaan pada anak berkebutuhan khusus yang ingin ia pahami. Hal tersebut diperoleh berdasarkan pernyataan Subjek 4 berikut, "anak berkebutuhan khusus umumnya lugu dan polos yang membuat mereka istimewa. Beda dengan anak normal. Interaksinya juga beda, kalau sama anak berkebutuhan khusus perlu waktu lebih lama tapi bisa lebih dekat interaksinya. Selama bekerja sebagai guru pendidikan luar biasa, saya juga lihat kalau orang tua juga kesulitan untuk mengasuh anak berkebutuhan khusus, jadi saya mau berusaha membantu di sekolah sesuai dengan kapasitas saya." Hal 
tersebut yang turut mendorongnya tetap menjadi guru pendidikan luar biasa, selain untuk mendapatkan penghasilan.

Pada dimensi self-acceptance, menjadi guru pendidikan luar biasa juga membuatnya lebih bersyukur dengan hidup yang dijalani sekarang. Subjek 4 juga merasakan banyak kegagalan yang ia alami sebelumnya, namun ia memilih untuk belajar dari kegagalannya. Subjek 4 juga menjadi lebih menyadari kekuatan dan kelemahan diri dalam pekerjaan. Hal tersebut diperoleh melalui pernyataan Subjek 4 berikut, “...dengan menjadi guru pendidikan luar biasa saya jadi bisa lebih kenal diri saya sendiri. Seperti kekuatan diri saya misalnya mudah beradaptasi, rajin dan sensitif yang membuat saya bisa mendidik siswa-siswa saya. Saya juga sadar kalau kekurangan saya misalnya moody yang membuat kadang-kadang saya menjadi galak kepada siswa. Tapi dengan melihat siswa-siswa saya yang berkebutuhan khusus, saya menjadi belajar untuk lebih bersyukur dengan apa yang saya miliki."

Jika ditinjau dari dimensi environmental mastery, yang menjadi tuntutan bagi Subjek 4 adalah adanya perbedaan antara program sekolah dengan orang tua yang membuat Subjek 4 selalu mengulang mengajarkan kepada siswa. Hal ini berusaha ia ubah dengan sering membangun komunikasi dengan orang tua. Hal tersebut diperoleh melalui pernyataan Subjek 4 berikut, "yang sulit itu kalau program sekolah tidak diterapkan di rumah, seperti toilet training, jadi harus selalu diulang di sekolah. Jadi masih ada saja anak yang mengompol padahal sebelum libur sudah tidak mengompol lagi. Tapi ya mau bagaimana lagi kan, jadi biasanya saya ajak diskusi lagi ibunya, saya ajak untuk mengajarkan di rumah juga supaya program sekolah tentang kemandirian bisa dikuasai oleh siswa." Selain itu, Subjek 4 juga sering mencari referensi terkait dengan materi pelajaran dan karakteristik anak berkebutuhan khusus untuk mendukung pekerjaannya sehari-hari.

Pada dimensi personal growth, Subjek 4 merasa tidak banyak perkembangan signifikan yang ia raih. Ia merasa dapat bekerja seperti saat ini dikarenakan adanya dukungan dari keluarga. Hal tersebut 
diperoleh melalui pernyataan Subjek 4 berikut, "saya tidak merasa memiliki perkembangan signifikan dalam kehidupan saya. Merasa biasa-biasa saja. Saya bisa seperti sekarang karena dukungan suami, kalau suami tidak mendukung juga tidak akan seperti sekarang ini.”

Pada dimensi purpose in life, menjadi istri dan ibu yang dapat dibanggakan oleh keluarga merupakan tujuan jangka panjangnya yang akan ia raih dengan membuat tujuan jangka pendek, yaitu melanjutkan pendidikan agar dapat meningkatkan pekerjaannya saat ini. Hal tersebut diperoleh melalui pernyataan Subjek 4 berikut, "saya hanya ingin menjadi manusia yang baik, menjadi ibu dan istri yang bisa dibanggakan. Kalau untuk pekerjaan saya ingin melanjutkan kuliah S2 dalam waktu dekat, kalau bisa" Jika ditinjau dari dimensi positive relation with others, demi mendukung pekerjaan, Subjek 4 membangun hubungan dekat dengan rekan guru satu unit dengan sering melakukan diskusi mengenai pekerjaan dan melakukan kegiatan bersama.

\section{DISKUSI}

Penelitian ini dapat menjelaskan psychological well-being pada guru pendidikan luar biasa di SLB X Bandung Barat dengan dimensi-dimensi pembentuknya. Terdapat persamaan dan perbedaan dalam dimensi pembentuk psychological well-being yang dimaknai oleh keempat partisipan. Jika ditinjau dalam dimensi self-acceptance terlihat cara individu menerima karakteristik diri dan kehidupan masa lalu. Keempat partisipan mampu menilai diri, termasuk kekuatan diri yang dijadikan faktor pendukung dalam pekerjaan dan kelemahan diri yang kemudian diatasi dengan kekuatan diri. Keempat partisipan pun menjadikan kegagalan yang dialami di masa lalu menjadi pelajaran dan motivasi dalam kehidupan saat ini. Secara umum, keempat partisipan berusaha untuk melakukan evaluasi dan perbaikan diri. Penemuan penelitian ini dalam dimensi self-acceptance sejalan dengan penelitian yang dilakukan oleh Platsidou (2010) yang menyatakan bahwa self-acceptance membuat guru menerima kekurangan dan kelebihan 
dirinya sehingga tidak memberikan evaluasi negatif terhadap kinerjanya. Dalam penelitian ini ditemukan bahwa guru berusaha optimal pada aspek lain meskipun guru merasa ada kekurangan pada satu aspek sehingga guru tetap menerima dirinya.

Penelitian yang dilakukan oleh Ilgan et al (2015) menunjukkan bahwa hubungan antara manusia dan lingkungan kerja yang mendukung merupakan variabel terpenting untuk memprediksi aspek psychological well-being guru. Hubungan interpersonal yang buruk dinilai sebagai penyebab stres kerja yang mengancam psychological well-being individu (Sliskovic \& Sersic, 2011). Penelitian ini menemukan bahwa keempat partisipan dapat membangun hubungan hangat dengan rekan-rekan guru dalam unit yang sama dalam dimensi positive relation with others. Hal ini dibangun dengan cara memberikan empati, kasih sayang, berkomunikasi, dan berdiskusi. Keempat guru menilai dirinya memiliki hubungan hangat dengan sesama rekan guru pendidikan luar biasa di unit sekolah luar biasa. Hubungan hangat ini dapat dimanfaatkan dalam kerja sama sebagai tim guru pendidikan luar biasa di SLB X Bandung Barat. Penemuan tersebut sesuai dengan penelitian Van Petegem et al. (2005; (Ilgan et al., 2015) yang membuktikan bahwa dukungan dari rekan kerja meningkatkan psychological well-being.

Pada praktiknya sebagai guru pendidikan luar biasa, keempat partisipan juga menghadapi tantangan seperti kurang kerja sama antara orang tua dan guru yang sering kali membuat guru harus mengulang pengajaran yang sudah diberikan sebelumnya. Pengulangan tersebut membuat guru kelelahan. Hal ini sesuai dengan hasil penelitian Wisniewski \& Gargiulo (1997; Platsidou, 2010) yang menyatakan bahwa guru pendidikan luar biasa rentan untuk mengalami stres karena mudah kelelahan dibandingkan dengan guru pendidikan umum. Dimensi positive relation with others membantu guru untuk tidak mengalami kelelahan emosional terkait dengan hubungan yang intens dengan siswa dan orang tua siswa. Saat mengalami kelelahan emosional setelah menghadapi siswa dan orang tua, guru dapat saling berdiskusi dan berbagi pengalaman. Hal tersebut dapat membantu guru untuk saling 
mendukung sesama kolega yang membuat kelelahan emosional yang dirasakan tidak mengganggu kinerjanya sebagai guru pendidikan luar biasa.

Keempat partisipan juga memiliki kecenderungan untuk menganggap siswa sebagai anak sendiri sehingga memiliki rasa kasih sayang kepada siswa berkebutuhan khusus. Hal tersebut terkait dengan status partisipan sebagai wali kelas bagi dua hingga empat anak sesuai dengan jenjang pendidikannya masing-masing. Penelitian yang dilakukan oleh Platsidou (2010) menunjukkan bahwa wali kelas cenderung memiliki psychological well-being yang lebih baik dibanding guru mata pelajaran karena lebih merasa terhubung secara personal pada siswanya. Penelitian yang dilakukan oleh Hargreaves (2000) juga menyatakan bahwa sumber penting motivasi dan kesenangan bagi guru adalah hubungan dengan siswa. Terdapat juga keterkaitan antara hubungan guru dan siswa dengan kesejahteraan guru (Spilt, Koomen, Thijs, 2011) dan pentingnya kelekatan personal antara guru dan siswa (Day \& Leitch, 2001). Feedback dan apresiasi langsung dari siswa juga meningkatkan psychological well-being guru. Kasih sayang kepada siswa berkebutuhan khusus membuat keempat partisipan tetap bertahan menjadi guru pendidikan luar biasa.

Jika ditinjau dalam dimensi purpose in life, yaitu adanya tujuan dan makna hidup pada individu, keempat partisipan memiliki tujuan jangka pendek dan jangka panjang. Dalam penelitian ditemukan perbedaan dimensi purpose in life yang dimaknai oleh keempat partisipan berdasarkan status perkawinan. Pada partisipan yang belum menikah, tujuan jangka panjang berupa suatu rencana untuk diri sendiri. Sedangkan, pada partisipan yang sudah menikah, tujuan jangka panjang merupakan tujuan bagi keluarga. Meskipun keempat partisipan memiliki tujuan yang berbeda, serta didukung dengan adanya ketertarikan pada anak berkebutuhan khusus, tujuan-tujuan tersebut tetap mendorong performa kerja partisipan sebagai guru pendidikan luar biasa. 
Pada dimensi environmental mastery, guru-guru cenderung mendapatkan tuntutan yang tinggi dari lingkungan, baik yayasan dan orang tua siswa. Waktu kerja yang cukup panjang menjadi dilema karena sebagian besar guru adalah perempuan yang sudah berkeluarga. Selain itu, terdapat tuntutan dari orang tua siswa yang menginginkan anaknya dapat disetarakan dengan perkembangan anak normal dan tidak melihat kondisi anak yang sebenarnya. Terdapat pula beberapa orang tua yang tidak melakukan program yang sama di rumah. Hal-hal tersebut menjadi kesulitan bagi biasanya menjadi bahan diskusi mengenai kesulitan yang dilakukan antara guru-guru pendidikan luar biasa di SLB X Bandung Barat. Pekerjaan untuk selalu mengulang pengajaran membuat guru merasa kelelahan dan terkadang mengalami stres. Kesulitan dan tuntutan pekerjaan juga memengaruhi psychological well-being para guru pendidikan luar biasa dalam bekerja.

Pada dimensi environmental mastery, meskipun merasa banyak mendapatkan tuntutan terkait dengan pekerjaan sebagai guru dari yayasan dan orang tua siswa, keempat partisipan cenderung menerima keadaan lingkungan dan berusaha untuk mengikuti tuntutan lingkungan dengan berperilaku tenang. Keempat partisipan juga memilih untuk tetap berkembang dalam lingkungan, seperti menambah ilmu dan keterampilan baru yang relevan dengan pekerjaan sebagai guru pendidikan luar biasa.

Temuan lainnya dalam penelitian ini adalah adanya perbedaan pada dimensi autonomy. Bagi guru yang belum menikah, ia mengarahkan dirinya sendiri untuk dapat mencapai tujuan personal. Di sisi lain pada guru yang sudah menikah, ketiga partisipan menjadikan keluarga sebagai sumber dukungan utama dalam kegiatan sehari-hari. Hal tersebut sejalan dengan penelitian Asada dan Ohkusa (2004) yang menyatakan bahwa pernikahan juga memiliki efek suportif pada fungsi emosional individu, merencanakan jadwal hidup dan menjalani kehidupan yang lebih terprogram (Ilgan et al., 2015). Keinginan guru untuk mengajar dan membantu anak berkebutuhan khusus juga sejalan dengan hasil penelitian Ryan dan Deci (2001; Zaki, 2018) yang menyatakan bahwa psychological well-being 
memberikan efek pada pengajaran karena seluruh upaya ini memiliki tujuan untuk berubah dalam kehidupan masyarakat menjadi lebih baik.

Jika ditinjau dalam dimensi personal growth, yaitu fungsi psikologis optimal yang membuat individu mengembangkan potensinya. Ketiga partisipan merasakan adanya perkembangan yang signifikan sebagai individu. Perkembangan yang dialami terkait penambahan pengetahuan dan keterampilan yang mendukung performa kerja sebagai guru pendidikan luar biasa. Sedangkan satu partisipan lainnya tidak merasakan adanya perkembangan. Ia merasa melakukan kegiatan sehari-harinya karena diberikan dukungan oleh keluarga.

Adapun keterbatasan dalam penelitian ini, terkait dengan jumlah sampel yang kecil. Hal ini memungkinkan masih terdapat variasi kesimpulan lain yang dapat dihasilkan dengan jumlah sampel yang lebih banyak. Selain itu, pada penelitian selanjutnya perlu menggali mengenai faktor-faktor yang memengaruhi psychological well-being untuk mendapatkan gambaran secara menyeluruh mengenai psychological well-being pada guru pendidikan luar biasa di SLB X Bandung Barat.

\section{KESIMPULAN DAN SARAN}

Penelitian ini memberikan gambaran mengenai keadaan psychological well-being guru Pendidikan luar biasa di SLB X Bandung Barat dalam menjalani pekerjaan untuk mengajar anak dengan kebutuhan khusus. Meskipun menemui rintangan dan tuntutan dalam pekerjaan, guru pendidikan luar biasa mampu menggunakan sumber daya yang dimiliki untuk mempertahankan dan meningkatkan performa kerja sebagai guru pendidikan luar biasa. Seluruh dimensi psychological well-being berperan bagi keempat partisipan sebagai guru pendidikan luar biasa. Dimensi self-acceptance berperan untuk menerima karakteristik diri, dimensi purpose in life berperan untuk meningkatkan pengetahuan dan keterampilan diri sebagai guru, dimensi positive relation with others berperan untuk menciptakan 
lingkungan saling mendukung sesama rekan guru guna menciptakan dimensi environmental mastery, dimensi autonomy berperan untuk mengarahkan diri mencapai tujuan sebagai guru pendidikan luar biasa, serta dimensi personal growth berperan untuk menghayati perkembangan diri yang mendukung performa kerja sebagai guru pendidikan luar biasa. Hasil penelitian ini dapat menjadi gambaran untuk merancang intervensi yang dapat digunakan untuk meningkatkan psychological well-being guru pendidikan luar biasa di SLB X Bandung Barat. Penelitian lanjutan dapat diawali dengan menambahkan data mengenai faktor-faktor yang memengaruhi psychological well-being guru pendidikan luar biasa kemudian merancang bentuk intervensi yang dapat diberikan untuk meningkatkan psychological well-being.

\section{DAFTAR PUSTAKA}

Braun, Virginia \& Clarke, Victoria. (2006). Using Thematic Analysis in Psychology. Qualitative Research in Psychology 2006; 3: 77-101.

Clarke, V., \& Braun, V. (2017). Thematic analysis. Journal of Positive Psychology, 12(3), 297-298. https://doi.org/10.1080/17439760.2016.1262613

Creswell, John W. (2007). Qualitative Inquiry \& Research Design: Choosing Among Five Approaches, Second Edition. USA: Sage Publications.

Creswell, John W. (2012). Educational Research: Planning, Conducting and Evaluating Quantitative and Qualitative Research, Fourth Edition. USA: Pearson.

Day, C. \& Leitch, R. (2001). Teachers' and teacher educators' lives: The role of emotion. Teaching and Teacher Education, 17(4), 403-415

Hargreaves, A. (2000). Mixed emotions: Teachers' perceptions of their interactions with students. Teaching and Teacher Education, 16(8), 811-826

Ilgan, A., Özü-cengiz, Ö., Ata, A., \& Akram, M. (2015). The relationship between teachers ' psychological well -being and their quality of school work life Öğretmenlerin okul iş yaşamı kaliteleri ve psikolojik iyi oluşları arasindaki ilişski, 3(2), 159-181.

Kim, S. Y., \& Lim, Y. J. (2016). Virtues and well-being of korean special education teachers. International Journal of Special Education, 31(1), 114-118.

Özü, Ö., Zepeda, S., Ilgan, A., Jimenez, A. M., Ata, A., \& Akram, M. (2017). Teachers' psychological well-being: a comparison among teachers in U.S.A., Turkey and Pakistan. International Journal of Mental Health Promotion, 19(3), 144-158. https://doi.org/10.1080/14623730.2017.1326397

Platsidou, M. (2010). Trait emotional intelligence of greek special education teachers in relation to 
burnout and job satisfaction. School Psychology International, 31(1), 60-76. https://doi.org/10.1177/0143034309360436.

Rothmann, S. I. (2014). Flourishing In Work And Careers. In M. Coetzer (Ed.), Perspectives On PsychoSocial Career Meta-Capacities (Pp. 203-220). New York, NY: Springer.

Ryan, R. M., \& Deci, E. L. (2001). On Happiness And Human Potentials: A Review Of Research On Hedonic And Eudaimonic Well-Being. Annual Review of Psychology, 52, 141-166. doi: DOI 10.1146/annurev.psych.52.1.141

Ryff, C. D. (2013). Psychological well-being revisited: Advances in the science and practice of eudaimonia. Psychotherapy and Psychosomatics, 83(1), 10-28. https://doi.org/10.1159/000353263

Sisask, M., Värnik, P., Värnik, A., Apter, A., Balazs, J., Balint, M., ... Wasserman, D. (2014). Teacher satisfaction with school and psychological well-being affects their readiness to help children with mental health problems. Health Education Journal, 73(4), 382-393. https://doi.org/10.1177/0017896913485742.

Sliskovic, A., \& Sersic, D.M. (2011). Work stress among university teachers: Gender and position differences. Archives of Industrial Hygiene and Toxicology, 62, 299-307.

Spilt, J. L., Koomen, H. M. Y., \& Thijs, J. T. (2011). Teacher Wellbeing: The Importance Of TeacherStudent Relationships. Educational Psychology Review, 23, 457-477. doi:10.1007/s10648-0119170-y.

Suherman, Y. (2012). Pengembangan Profesi. PLB FIP UPI.

Van Petegem, K., Creemers, B. P., Rossel, Y., \& Aelterman, A. (2005). Relationships between teacher chracteristics, interpersonal teacher behaviour and teacher wellbeing. Journal of Classroom Interaction, 40(2), 34-43

Wisniewski, L. and Gargiulo, R. M. (1997). Occupational Stress and Burnout among Special Educators: A Review of the Literature, The Journal of Special Education 31: 325-46.

Zaki, Saman. (2018). Enhacing Teacher Effectiveness Through Psychological Well-Being: A Key to Improve Quality of Teachers. International Journal of Research in Social Sciences Vol. 8 Issue 7, July 2018, ISSN: 2249-2496 